Historia Slavorum Occidentis

2020, nr 3 (26)

ISSN 2084-1213

DOI: $10.15804 /$ hso200304

\author{
Matgorzata Gumper (Poznań)
}

ORCID: 0000-0003-4715-0447

\title{
Podróże edukacyjne dziewcząt w Galicji w XIX i XX w.- studium przypadku rodziny Załuskich
}

Słowa kluczowe: migracje, podróże dydaktyczne, edukacja dziewcząt, szkoła dziewiętnastowieczna, Galicja

Keywords: migrations, didactic travels, education of girls, nineteenth-century school, Galicia

\begin{abstract}
The article shows the changes in the education of girls from magnate families in Galicia in the $19^{\text {th }}$ century. The memories of didactic travels of the women from the Załuski family were analyzed. Studies shows how young ladies learned under the tutelage of governess.
\end{abstract}

Prezentowany szkic ma na celu ukazać na wybranych przykładach, jak przebiegały i jaki wpływ na organizację życia rodzinnego miały podróże edukacyjne, odbywane przez dziewczęta z terenów Galicji w okresie zaborów. Podjęłam w nim próbę zarysowania problemu zarówno z uwzględnieniem zaangażowania matek, jak i aktywności samych podopiecznych. Rezygnując świadomie z tradycyjnego wstępu, poniższy artykuł pragnę rozpocząć od przytoczenia cytatu, który w skróconej formie obrazuje stereotyp dotyczący kształcenia panien z dobrych domów w XIX w. Streszcza on trafnie podział funkcji w rodzinie, formę przekazywania wiedzy i zakres materiału dydaktycznego:

Podczas gdy jej bracia zaprzątali sobie w szkołach [...] głowy łaciną, matematyką, geografią i innymi równie skomplikowanymi dyscyplinami naukowy- 
mi, młoda panienka - kształcona w zaciszu domowym - miała edukację zdecydowanie ułatwioną. Podstawowymi umiejętnościami, jakie musiała zdobyć, były ładne i składne pisanie oraz rachunki w najprostszej formie. Oprócz tego powinna posiąść trochę wiadomości z historii ojczystej, niewiele $\mathrm{z}$ historii powszechnej, historii naturalnej, co nieco z geografii. Wypadało też, by nauczyła się szczebiotać w językach obcych i oczywiście czytać. [...] Wprowadzano także elementy chemii, oczywiście w wymiarze odpowiadającym potrzebom pani domu (farbowanie płócien czy produkcja świec), fizyki (uczono o cieple, ogniu, elektryczności, świetle, kolorach) czy prawa (podstawowe pojęcia jak testament czy mienie). Bardzo ważne było praktyczne kształcenie dziewczynki. Obiegowa opinia głosiła, że pomoc matce $\mathrm{w}$ obowiązkach pani domu jest dla nastolatek wręcz pożądaną rozrywką ${ }^{1}$.

Przywołany fragment wydaje się na tyle wyczerpujący, że zasługuje na miano rozbudowanej definicji zjawiska kształcenia córek z dobrych rodzin w XIX stuleciu. Ostatnie zdanie zwraca uwagę na pierwszorzędną rolę matek w tym procesie, co zostało przebadane i opisane w licznych pracach na temat edukacji domowej okresu zaborów, m.in. przez Krzysztofa Jakubiaka i Adama Winiarza². Małgorzata Stawiak-Ososińska wskazywała, że „odpowiednie wychowanie dziewcząt było sprawą niezmiernie ważną $\mathrm{i}$ trudną ${ }^{\prime 3}$, także z powodu promowania tego zagadnienia przez popularne czasopisma, jak np. krakowskie „Kalina” i „Niewiasta”. W ten sposób obowiązki macierzyńskie lokowały się pośród innych ważnych dla społeczeństwa tematów, co „służyło szczytnym wartościom - uczciwej pracy, energii i wytrwałości oraz żywej wierze w to, co polskie"4. Pozostaje jeszcze do rozważenia zagadnienie,

1 A. Zaprutko-Janicka, Jak wygladało życie XIX-wiecznych nastolatek?, https://ciekawostkihistoryczne.pl/2012/04/15/jak-wygladalo-zycie-xix-wiecznych-nastolatek/\#2 [dostęp 4 VI 2019]. 2 K. Jakubiak, Wizerunek matki i jej edukacja w świetle piśmiennictwa pedagogicznego i pamiętnikarstwa XIX wieku i początków XX wieku, [w:] Rola i miejsce kobiet w edukacji i kulturze polskiej, red. W. Jamrożek, D. Żołądź-Strzelczyk, t. 2, Poznań 2001.

3 M. Stawiak-Ososińska, Wychowanie domowe dziewcząt w świetle pogladów publicystów pierwszej połowy XIX wieku $w$ Królestwie Polskim (rola i zadania matki $w$ domowym wychowaniu córek), Studia Pedagogiczne. Problemy Społeczne, Edukacyjne i Artystyczne 14 (2003), s. 289.

4 M. Stawiak-Ososińska, Rola matki w wychowaniu i kształceniu dzieci w świetle artykułów $z$ krakowskich czasopism kobiecych "Niewiasty” i „Kaliny”, Wychowanie w Rodzinie 2 (2011), s. 17; o ideach wychowawczych w okresie zaborów więcej w: Studia problemowe $z$ historii wychowania na ziemiach polskich w XIX-XX wieku, red. E. Juśko, J. Kamińska-Kwak, R. Pelczer, Tarnów 2015. 
które miało olbrzymi wpływ na sposób przyjmowania wiedzy przez młode damy oraz codzienną organizację życia przez ich matki, a bywa pomijane jako czynnik rzekomo mało istotny. Mowa o ciągłej, wieloletniej migracji rodzin, powodowanej koniecznością wykształcenia licznej grupy dzieci, zróżnicowanych wiekowo i przejawiających nieraz bardzo różne predyspozycje. Rody arystokratyczne przemieszczały się bez ustanku po zamieszkiwanym państwie oraz kontynencie europejskim, przez co miejsce nauczania córek - przywołane zacisze domowe - stawało się pojęciem jedynie symbolicznym. Nauczanie domowe, nazywane zamiennie prywatnym, funkcjonowało w Rzeczypospolitej od XVIII w., zaś „w wieku XIX, mimo postępującej demokratyzacji szkolnictwa, edukacja domowa - jako alternatywna forma kształcenia - była realizowana we wszystkich państwach europejskich, zwłaszcza na poziomie początkowym" . W rzeczywistości jednak podróże dziewcząt, w ślad za braćmi przechodzącymi przez kolejne etapy oficjalnej edukacji, nie miały wiele wspólnego ze wspomnianym zaciszem, i otwierały im drogę do ciągłego wzbogacania swej wiedzy o świecie oraz własnych kompetencji społecznych. Wyraźnie dostrzegamy to zjawisko na przykładzie rodziny Załuskich, której wybranych członków zaprezentuję w niniejszej pracy. Skupię się na wkładzie kobiet-matek ${ }^{6} \mathrm{w}$ realizowanie tradycyjnego modelu wychowania córek, ich wysiłku oraz wynikającej z niego ruchliwości migracyjnej. Temat wpisuje się w zagadnienie mitu miłości macierzyńskiej, który zrodził się w środowisku magnackim w osiemnastowiecznej Rzeczypospolitej, by następnie, analogicznie do edukacji, obejmować coraz szersze kręgi społeczne. W okresie zaborów utrzymywał się też tradycyjny układ, w którym w przypadku rodzin magnacko-arystokratycznych i szlacheckich wpływ „Pani Matki” był duży, a jej pozycja prawie równorzędna z pozycją towarzyską mężów ${ }^{7}$. Jolanta Syguła pisała w tym kontekście o kobiecie jako przewodniczce, prowadzącej swe potomstwo w przyszłość i strzegącej przestrzeni domowego ogniska ${ }^{8}$. Jak ukażę w niniejszym

5 Jakubiak K., Polskie tradycje edukacji domowej, Studia Pedagogica Ignatiana 20 (2017), No. 3: Edukacja domowa. Stan i perspektywy, s. 23; https://apcz.umk.pl/czasopisma/index. $\mathrm{php} /$ SPI/article/view/SPI.2017.3.001 [dostęp 13 VI 2019].

6 Więcej o roli kobiet w edukacji m.in. w: Działalność kobiet polskich na polu oświaty i nauki, red. W. Jamrożek, D. Żołądź-Strzelczyk, Poznań 2003; Rola i miejsce kobiet w edukacji i kulturze polskiej. Konferencja naukowa, Zajączkowo 20-22 października 1997 (tezy i streszczenia referatów), red. W. Jamrożek, D. Żołądź-Strzelczyk, Poznań 1997; W. Jamrożek, D. Żołądź-Strzelczyk, Studia z dziejów edukacji kobiet na ziemiach polskich, Poznań 2001.

7 J. Sygula, Pozycja i rola kobiety $w$ rodzinie, s. 65.

8 Tamże, s. 59. 
artykule, z czasem dochodziło także do wzrostu zainteresowania panien z dobrych domów sprawami edukacji wiejskiej, co mogło wynikać z przemian kulturowych oraz ekonomiczno-społecznych ${ }^{9}$, ale w przypadku omawianych postaci nie wpłynęło na ograniczenie ich własnej migracji za wiedzą.

Amelia Ogińska przyszła na świat w 1805 r. w litewskim Zalesiu, gdzie spędziła pierwsze dwa lata życia, zanim wyruszyła wraz ze swymi rodzicami - księciem Michałem Kleofasem Ogińskim i księżną Marią de Neri Ogińską - w wieloletnią podróż po Europie. Po dwuletnim pobycie we Florencji, rodzina w 1809 r. udała się do Paryża, z zamiarem pozostania tam w następnych latach. Okresu paryskiego dosięgają najwcześniejsze wspomnienia księżniczki, która opowiadała swym dzieciom po latach:

$\mathrm{Z}$ naszym mieszkaniem połączony był piękny ogród, w głębi którego stał dom, zajęty przez pensyonat dla panienek. Było ich tylko ośm, bardzo starannie wychowanych. Godziny rekreacyjne miałyśmy wspólne, więc ochoczo uczestniczyłam w rozrywkach pensyonarek, i bardzo się przywiązałam do jednej z nich, Róży Potockiej $[. . .]^{10}$.

We Francji nastąpił początkowy etap edukacji Amelii, uwzględniający nowoczesne metody dydaktyczno-wychowawcze. Pierwsza nauczycielka, Mademoiselle Férice, otrzymała zadanie w prowadzenia dziewczynki w świat nauki przez zapoznanie jej z podstawami wszelakiej wiedzy. Czynności propedeutyczne musiała wykonywać bardzo fachowo, skoro dorosła już Amelia wyraziła się o niej w sposób niedwuznaczny:

Posiadała wszystkie przymioty, jakiemi się podbija serca i rozwija umysły młodzieży. W nauczaniu trzymała się metody odmiennej od tych wszystkich, jakie poznać miałam sposobność. Jej nauka była pociągająca, czasem zabawiająca, a umiała budzić zajęcie nawet dla przedmiotów abstrakcyjnych ${ }^{11}$.

Następnie narratorka przeszła do opisów przebiegu lekcji, do których powracała z dużą dozą sentymentu, odsłaniając urocze w jej odczuciu szczegóły działań Mademoiselle Férice. Dowiadujemy się, iż:

9 W swej pracy o działalności Anastazji Dzieduszyckiej Joanna Falkowska poruszyła kwestię walki polskich kobiet w drugiej połowie XIX w. o dostęp do oświaty na szczeblu średnim i wyższym; J. Falkowska, „Przeciw marzycielstwu”. Działalność edukacyjna Anastazji z Jełowickich Dzieduszyckiej (1842-1890), Toruń 2014, s. 7 n.

10 K.B. Załuski, Wspomnienia o rodzinie Załuskich w XIX stuleciu, Kraków 1907, s. 93-94. Autor przytacza fragmenty z pamiętnika swej matki, Amelii z Ogińskich Załuskiej.

11 Tamże, s. 94. 
długą laseczką, którą nazywała różdżką mądrości, wskazywała na pewne punkta kart geograficznych [...] na ziemi rozłożonych wokół swej uczennicy; że czarna tablica służyła do pisania za dyktowaniem, i do analiz gramatycznych, zaś wynik lekcyi wykazywał protokolik nie słowy, ale znakami sprytnie skombinowanymi ${ }^{12}$.

Bliska relacja na płaszczyźnie mistrz-uczeń była utwierdzana również w bardziej prywatnej atmosferze. Wskazuje na to fragment będący kontynuacją przytoczonego cytatu: „We czwartki, w nagrodę za moją pilność, bywała u nas na obiedzie, a potem opowiadała mi zajmujące mitologiczne baśnie, i ślicznie wygłaszała bajki La Fontaine’a”13. Późniejsze metody nauczania, jakie stosowała Amelia wobec swych dzieci, wskazują na to, że wyobrażenie procesu edukacji wyniosła ona z własnych doświadczeń we Francji.

Wspomniana współpraca Amelii z Mademoiselle Férice trwała przez kilka lat, a konieczność jej przerwania była ciężkim przeżyciem dla dziewczynki, doprowadzając ją do płaczu w chwili rozstania. Wydarzenia polityczne zmusiły Marię Ogińską do wyjazdu do Petersburga w momencie największej chłonności umysłu córki, w ósmym roku jej życia. Kolejna bardzo odległa podróż okupiona została silnymi emocjami, jednak przyniosła szereg cennych doświadczeń. Przemieszczano się, zamówioną u „najlepszego fabrykanta [...] karetą żółtą, białym atłasem wewnątrz wybitą" ${ }^{14}$. Wraz z Amelią Paryż opuszczało jej młodsze rodzeństwo: Emma i Ireneusz, oraz siedmioosobowa świta ich matki. Aby umilić czas podróżującym dzieciom, bona Pauline „opowiadała przygody Kopciuszka i śpiewała piosenki ludowe”" ${ }^{15}$, ich matka zaś stale w zasięgu ręki miała swą gitarę w kształcie liry, „na której do śpiewu sobie wtórowała" ${ }^{16}$. Mimo tych starań ze względu na długość wyprawy nie było możliwe uniknięcie licznych nieprzyjemności i utrudnień. Oto przejazd przez pasmo zalesionych gór na obszarze Wielkiego Księstwa Badeńskiego, „uchodzącego za gniazdo zbójców”, miał napełnić Amelię „strachem nigdy nie zapomnianym” ${ }^{17}$. Z kolei trasa z Królewca do Kłajpedy [niem. Memel] „była najniewygodniejszą w świecie. Po jednej stronie, morze ponure i huczące; po drugiej piaski tak głębokie, że nie można było po nich jechać, jeno dwoma kołami w wodzie. [...] Dla głębokości piasku niemożliwem było wysiąść, aby pójść spożyć gdzieś obiad lub wieczerzę, tymczasem

\footnotetext{
Tamże.

13 Tamże.

14 Tamże, s. 98.

15 Tamże, s. 99.

16 Tamże.

17 Tamże.
} 
zapasy żywności rychło się wyczerpały" ${ }^{18}$. Z licznych tego typu zapisów wynika, że przymusowe, długodystansowe wyprawy bywały jednymi z nielicznych okoliczności, w których dzieci z rodów arystokratycznych uczyły się znosić ciężkie warunki, co hartowało ich ducha, uzupełniając bogaty rozwój intelektualny. Już jako dojrzała kobieta i żona Karola Teofila Załuskiego Amelia dla wielu rodzin małopolskich stała się wzorem „przykładnej matki” ${ }^{19}$ i tak też była nazywana przez męża. Po przybyciu Załuskich do Iwonicza w $1837 \mathrm{r}$. ziemie galicyjskie stały się obszarem aktywnej działalności rodziny, której następne pokolenia kontynuowały renowację i rozbudowę tamtejszego uzdrowiska. Zaangażowanie to wynikało po części ze świadomości, że Iwonicz może stać się długo wyczekiwaną przystanią i miejscem docelowym wieloletniej tułaczki, na jaką Karola i Amelię skazały represje po powstaniu listopadowym, w tym konfiskata dóbr na Litwie. W rzeczywistości rozpoczynał się nowy, odmienny od poprzedniego, etap migracji, dla którego Galicja była swoistą „bazą wypadową” i punktem odniesienia dla tożsamości terytorialnej rodu.

Szczególną uwagę mieszkańców Iwonicza, oraz przybywających do niego gości i kuracjuszy, zwracało podejście hrabiny Załuskiej do sprawy kształcenia swych pociech, dla których w okresie dziecięcym pozostawała główną nauczycielką. Prowadziła z nimi lekcje języka francuskiego, angielskiego i włoskiego, a także kartografii, arytmetyki, tańca, gry na pianinie, czytania na głos i deklamacji. Według wspomnień miejscowych przygotowywała także córki do pielęgnacji potrzebujących ${ }^{20}$. W swym dziele pt. Wspomnienia o rodzinie Zatuskich w XIX stuleciu jej syn Karol Bernard zapisal, iż „starsze córki towarzyszyły nieraz matce w odwiedzaniu chorych i biednych, a zdarzało się, że wdzięczni chałup mieszkańcy przechodzące dworskie dzieci na podwieczorek zapraszali, kwaśnem mlekiem i razowym chlebem je podejmując"21. Niektóre z „lekcyi rozmaitych [...] odbywały się chodząco, w ogrodzie”22. Pomagało to pogodzić potrzeby rozwojowe grupy zróżnicowanej wiekowo - Amelia „wtenczas z pamięci uczyła jednych wierszy Krasickiego lub Niemcewicza, drugich gramatyki polskiej i francuskiej, pilnując przytem najmłodszych dzieci zajętych brukowaniem ścieżek kamieniami na gazonach zbieranymi" ${ }^{23}$. Pewne obszary odbywanej wspólnie

\footnotetext{
18 Tamże.

19 A. Kwilecki, Z Kwilcza rodem. Wspomnienia i szkice, Poznań 2012, s. 87.

20 Tamże.

21 K.B. Załuski, dz. cyt., s. 11.

22 Tamże, s. 10, 11.

23 Tamże, s. 11.
} 
edukacji domowej nie przebiegały analogicznie dla dziewcząt i chłopców. „Panienki i chłopczyki mieli odrębne przyrządy gimnastyczne, w pokojach i na dworze; dla pierwszych sprawiano małe żarna, które kręciły na przemian prawą i lewą ręką [...]; chłopcy jeździli na kucykach, panny, nie tak wcześnie, na rosłych koniach”24. Stosując nowoczesne metody wychowywania, matka wzorowała się na zasadach angielskich $^{25}$. Pracowite życie upływało we względnej stabilizacji, jaką zapewniło osiedlenie się rodziny. Z czasem nastąpił jednak etap edukacji szkolnej najstarszego syna, Michała Karola, który przywrócił dla Amelii, doświadczany przedtem w dzieciństwie i młodości, wieloletni okres niekończących się podróży. Już jako wdowa wyjeżdżała często z Iwonicza do Wiednia, gdzie jej synowie pobierali nauki w tzw. Terezjanum (Theresianum), czyli Cesarsko-Królewskiej Terezjańskiej Akademii Szlacheckiej ${ }^{26}$. Niejednokrotnie w swoich listach do siostry Emmy skarżyła się na trudności, jakie wynikały z długości pokonywanej trasy ${ }^{27}$. Najpierw docierała do Krakowa bryczką, co zajmowało trzy dni i wymagało dwóch postojów noclegowych. Drugi etap - z Krakowa do Lipnika - odbywała wozem pocztowym, by wreszcie stamtąd koleją żelazną dojechać do Wiednia ${ }^{28}$. Wspominając pierwszą taką wyprawę matki, która przypadła w okresie rabacji galicyjskiej, Karol Bernard tak zobrazował jej doświadczenia:

Na samej kolei panowało w stacyach ciągłe jeszcze zamieszanie, wskutek trudności dostania się, poprzez szyny, śród ustawicznego ruchu pociągów, do wagonów, i znalezienia w nich, przy wielkim natłoku podróżujących, zwłaszcza w dniach ogólnej z Galicyi ucieczki rodzin obywatelskich, dość miejsc dla kilku osób razem nierozdzielnie jadących ${ }^{29}$.

\footnotetext{
24 Tamże.

25 Tamże. zespolonych”, K.B. Załuski, dz. cyt., s. 17.

27 Zob.: H. Wysocki, Przemówiły stare listy, Kraków 1986.

26 We Wspomnieniach o rodzinie Załuskich... Karol Bernard przytoczył opowieść, którą jego ojciec podzielił się z dziećmi pod nieobecność swej żony, gdy ta w 1842 r. udała się do Wilna w sprawach majątkowych. Hrabia Karol Teofil miał wówczas przygotowywać mentalnie słuchaczy do czekających ich podróży, mówiąc o latach własnej młodości: „Po niejakim czasie ojciec zawiózł mnie do Krakowa, abym się przygotował do szkół w Wiedniu, gdzie mój starszy brat, Józef, już od kilku lat pobierał nauki w Terezyanum, akademii fundowanej przez Cesarzową Maryę Teresę, celem zbliżenia do siebie rodzin szlacheckich wszystkich krajów pod Jej berłem 
Arystokratyczny wymóg godnego wykształcenia synów oraz obeznania córek z obyczajami europejskimi doprowadzał, zwłaszcza rodziny wielodzietne, do sytuacji ciągłego przemieszczania się. „Od 1846 r. przez około dziesięć lat Amelia Załuska dużo przebywała w Wiedniu, na ogół jednak od jesieni do wiosny, by być blisko kształcących się synów, spędzać z nimi większość niedziel, ćwiczyć ich w znajomości języków i wspólnie czytać utwory literackie”30. W czasie wolnym rodzina odbywała liczne podróże. Po zaledwie kilkutygodniowym wypoczynku w stolicy Austrii hrabina Załuska wraz z dziećmi: Michałem, Marią, Emmą i Karolem, złożyła wizytę u swej matki, Marii, która poddawała się wówczas kuracjom wodoleczniczym w oddalonym o ponad 300 km od Wiednia śląskim miasteczku Freiwaldau ${ }^{31}$. Nadarzyła się zatem okazja do porównania funkcjonowania uzdrowiska utworzonego przez Vincenza Priessnitza z ośrodkiem prowadzonym przez Załuską w Iwoniczu. Celem wycieczek krajowych i zagranicznych (np. do Włoch) było także zwiedzanie zabytkowych miejsc, centrów kultury oraz udział w wydarzeniach artystyczno-kulturalnych bądź spotkaniach o podłożu patriotycznym. Te ostatnie wymagają szczególnej uwagi, gdyż pełniły funkcję niezwykle istotną w czasach stopniowego zanikania polskiego narodu szlacheckiego na europejskiej scenie zmagań politycznych. Dzięki bogatemu życiu towarzyskiemu dziewiętnastowiecznej arystokracji polskiej, młodsze pokolenia przyszłych żon, matek i pań domu miały okazję doświadczać „tożsamości utraconej”. Przekazały ją następnie w formie „polskości zapamiętanej”, przygotowując swe dzieci na sprostanie burzliwym wydarzeniom pierwszej połowy XX w. Jednym z wiedeńskich centrów tej cennej transmisji tożsamościowej stał się dom hrabiny Heleny z książąt Lubomirskich Mniszek, w którym gościły często panny Załuskie wraz z matką i braćmi. Przytoczmy ogólne wrażenie, jakie pozostało po tych spotkaniach w pamięci Karola Bernarda:

Już przy wejściu do sieni i przedpokoju witała wchodzących polska mowa odźwiernego i służących, a umeblowanie salonu przypominało czasy naszych praojców. Jedna z najstarszych Dam pałacowych (...), sędziwa pani domu przyjmowała z wdziękiem iście staropolskim, zewsząd otoczona czcią i miłością należną wiekowi, świetności rodu i niewyczerpanej dobroci ${ }^{32}$.

\footnotetext{
30 A. Kwilecki, Załuscy w Iwoniczu 1799-1944, Kórnik 1993, s. 73-74.

31 Miejscowość tę podaje Załuski we Wspomnieniach o rodzinie Załuskich..., zapisaną w formie „Freywaldau”. Chodzi o Jesionik (pol. Frywałdów, Frywałd), obecnie czeskie miasto położone w Górach Opawskich, w którym do dnia dzisiejszego istnieje sanatorium lecznicze założone w 1822 r. przez Vincenza Priessnitza, K.B. Załuski, dz. cyt., s. 55; zob.: https://www.navstivtejeseniky.cz/pl/cel/priessnitzovy-lecebne-lazne-jesenik [dostęp 11 VI 2019].
}

32 K.B. Załuski, dz. cyt., s. 62. 
W bliższej perspektywie przebywanie w środowisku magnacko-arystokratycznym stwarzało warunki osobistego rozwoju starszych córek Amelii. Poznawane obyczaje i poglądy były następnie odpowiednio modelowane, musiały bowiem odpowiadać realnym wyzwaniom pełnego trudów życia w zaborze austriackim. „W czasie długich pobytów w Wiedniu lub w okolicach Wiednia, blisko synów i w stałym kontakcie z Akademią Terezjańską, Amelia zajmowała się bezpośrednio córkami(...). Oczywiście, szczególnej opieki ze strony matki wymagały dwie najstarsze córki: Maria i Emma. WWiedniu uczyły się śpiewu i muzyki, nabierały ogłady towarzyskiej, przygotowywały się do późniejszych obowiązków rodzinnych i domowych”33. Standardową konsekwencją tego typu kształcenia było szybkie znalezienie pannom współmałżonków. Obie wyszły za mąż już w 1849 r.: Emma została żoną Teofila Ostaszewskiego ze Wzdowa, Maria związała się z Władysławem Gołaszewskim z Targowisk. Tym sposobem, mając odpowiednio osiemnaście i dwadzieścia lat, zakończyły etap edukacji. Wiedeń nie był jedynym celem podróży rodzinnych. Amelia umożliwiała również Emmie rozwijanie jej naturalnych predyspozycji, tym cenniejszych, że wpisujących się w tradycję dziedziczoną po samym księciu Michale Kleofasie Ogińskim ${ }^{34}$. Karol Bernard uwiecznił na kartach swych Wspomnień o rodzinie Załuskich... pewne wydarzenie, które zadecydowało o kierunku dalszej migracji dydaktycznej:

Zbadawszy szczegółowo grę panny Emmy w czytaniu nut i wykonywaniu z pamięci klasycznych utworów, profesor wyższej klasy wiedeńskiego konserwatoryum, p. Pirkert, oświadczył iż jej lekcyi dawać nie może. (...) „Nauka którą pobierała hrabianka nie potrzebuje żadnego uzupełnienia. Najlepsza moja uczennica w konserwatoryum nie dorównuje córce pani”35.

- poinformował hrabinę Załuską, którą taki obrót spraw całkowicie zaskoczył.

Inwestycja w talent muzyczny wymagała posłania córki do Lwowa, gdzie funkcjonowało Galicyjskie Towarzystwo Muzyczne. Tam, pod okiem założyciela konserwatorium, cenionego kompozytora i wirtuoza Karola Mikulego ${ }^{36}$, dziewczyna doskonaliła się jako pianistka. Wiedeń, Lwów i Iwonicz stały się więc niektórymi z licznych „punktów postojowych”, w których Amelia zatrzymywała się na chwilę, przed wyruszeniem w dalszą drogę. Również młodsze córki hrabiny Załuskiej, bę-

33 A. Kwilecki, Zatuscy w Iwoniczu..., s. 75.

34 Michał Kleofas Ogiński był ojcem Amelii Ogińskiej, a dziadkiem m.in. wspomnianych Emmy, Marii i Michała Karola.

35 K.B. Załuski, dz. cyt., s. 57.

36 https://culture.pl/pl/tworca/karol-mikuli [dostęp 7 VI 2019]. 
dące zarazem najmłodszymi z dziewięciorga jej dzieci, w okresie swej edukacji udały się do Wiednia, zajmując przy boku matki miejsce swych zamężnych już starszych sióstr. Wcześniej Amelia na czas wyjazdów zostawiała Idę (ur. 1841) i Franciszkę (ur. 1843) w Krakowie pod opieką swej siostry, Emmy Wysockiej. Na lata pięćdziesiąte XIX w. przypadł okres nasilenia się objawów ciężkiej choroby Amelii, która miała wkrótce poddać się poważnej operacji. Nie dysponując już takimi siłami, jak w 1846 r., zdecydowała się wybrać inny sposób edukacji dla dziewczynek. Przekazała je pod opiekę sióstr wizytek, których klasztor został ufundowany na początku XVIII w. przez Wilhelminę Amalię, wdowę po cesarzu Józefie I. Po poświęceniu świątyni w 1719 r., szybko zrealizowano życzenie cesarzowej, otwierając przyklasztorną szkołę dla dziewcząt ze zubożałej arystokracji oraz z rodzin mieszczańskich ${ }^{37}$. W tym właśnie miejscu Ida i Franciszka „w osobie siostry Ludwiki de Pilat znalazły najtroskliwszą opiekunkę, w siostrze Ada Revitzky doskonałą nauczycielkę muzyki, a w towarzyszkach panienki z najznakomitszych domów austryackich i węgierskich" ${ }^{38}$. Na tym przykładzie widzimy, że na przestrzeni jednego pokolenia uległ zmianie tryb kształcenia córek, z których starsze przez dłuższy czas pozostawały pod protekcją matki-nauczycielki, młodsze zaś pobierały już nauki w szkole sióstr „salezjanek na Rennwegu”39. Uzależnione to było przede wszystkim od wieku i stanu zdrowia Amelii Załuskiej. Zmiana nie objęła natomiast najważniejszego czynnika, który nadal pozostawał niezbędny, aby docierać do źródeł wiedzy i ognisk kultury. Na wykluczenie „migracji dydaktycznej” było jeszcze za wcześnie. Po śmierci Karola (1845) i Amelii (1858) Załuskich, pełnoprawnym właścicielem Iwonicza, aktywnie działającym na rzecz rozwoju uzdrowiska, został ich najstarszy syn - hrabia Michał Załuski. Nastały czasy dające nadzieję na ograniczenie przymusowych podróży, gdyż część rodziny ulokowała się również na ziemiach galicyjskich. Siostry Maria i Emma zamieszkały ze swymi mężami odpowiednio we Wrocance i Wzdowie.

W 1878 r. probostwo w parafii iwonickiej objął ks. Antoni Podgórski. Uznał on opiekę nad społecznością wsi i jej rozwojem za priorytet swej posługi ${ }^{40}$. Jego dążeniu

37 https://www.deon.pl/religia/kosciol-i-swiat/z-zycia-kosciola/art,506,austria-400-lecie-wiedenskich-wizytek.html [dostęp 12 VI 2019].

38 K.B. Załuski, dz. cyt., s. $86-87$.

39 https://www.deon.pl/religia/kosciol-i-swiat/z-zycia-kosciola/art,506,austria-400-lecie-wiedenskich-wizytek.html [dostęp 8 VI 2019].

40 Ocaleni od zapomnienia. Stary cmentarz w Iwoniczu, red. M. Bliżycki, Krosno 2018, s. 18-19, http://www.ocaliwonicz.pl/wp-content/uploads/2017/11/Informator-Iwonicz-finalny-druk.pdf [dostęp 5 VI 2019]. 
sprzyjał częściowo system organizacji szkolnictwa w Austrii, gdyż na jej terenie od 1869 r. wprowadzone zostały bezplatne, publiczne, obowiązkowe i międzywyznaniowe szkoły ludowe ${ }^{41}$. W artykule siedemnastym Zasadniczej ustawy państwowej z 21 grudnia 1867 r. o ogólnych prawach obywateli państwa zapisano, że „nauka i nauczanie są swobodne” ${ }^{42}$, artykuł dziewiętnasty zaś zapewniał, iż „Wszystkie ludy w państwie są równouprawnione, a każdy naród ma zabezpieczone prawo zachowania i pielęgnowania swej narodowości i swego języka”. Zarazem Zasadnicza ustawa państwowa z $25 \mathrm{~V} 1868$ r., mocą której „wydaje się zasadnicze postanowienia względem stosunku szkoły do kościoła”43, odrzucała część postanowień konkordatu z 1855 r., odnoszących się do edukacji ludowej. Wprowadzała niezawisłość szkół od kościoła, poddając je pod najwyższe kierownictwo państwowe. Kolejne paragrafy pozostawiały jednak parafiom przestrzeń do działania: „Kościołowi i stowarzyszeniom religijnym dozwolono własnymi środkami zakładać i utrzymywać szkoły z prawem szkół publicznych, jeżeli uczyni się zadość wszystkim prawnym warunkom, zaś ustawami nie jest zakazane, aby korzystali ze szkół tych członkowie innego stowarzyszenia"44 ( $\$ \$ 4,9,10,55)$.

Cennym przedsięwzięciem ks. Podgórskiego było sprowadzenie przezeń w $1883 \mathrm{r}$. sióstr felicjanek, które zajęły się edukacją dziewcząt wiejskich ${ }^{45}$, ukierunkowaną na wykształcenie kultury osobistej, podstawowej wiedzy o świecie i umiejętności praktycznych związanych z gospodarstwem domowym (np. gotowania, szycia, dziewiarstwa, przędzenia). Zajęcia prowadzono w niewielkim drewnianym klasztorze. Z czasem zaistniała jednak konieczność zagospodarowania na rzecz nauki większych przestrzeni. Skłoniło to ks. Podgórskiego do postawienia budynku murowanego. Pełnił on nie tylko funkcję nowej siedziby klasztoru oraz szkoły dziewczęcej, powstał tam również sierociniec im. św. Kazimierza dla dzieci płci żeńskiej. W biogramie proboszcza, utworzonym w ramach projektu Iwonickiego Stowarzyszenia „Ocalić od zapomnienia”, dokonano pozytywnego podsumowania działalności zakonu. „Przy klasztorze sióstr felicjanek w Iwoniczu skupiało się odtąd życie religijne i kulturalne wioski i parafii, a sieroty

\footnotetext{
41 J. Miąso, Szkolnictwo w XIX-wiecznej Europie i początki pedagogiki porównawczej w Anglii, Rozprawy z Dziejów Oświaty 46 (2009), s. 91.

42 Zob. T. Fiutowski, Szkolnictwo ludowe w Galicyi w dobie porozbiorowej, Lwów 1913, s. 33, http://pbc.up.krakow.pl/dlibra/plain-content?id=3496 [dostęp 4 VI 2019].

43 Zob. tamże, s. 34.

44 Tamże.

45 Więcej o szkolnictwie elementarnym na terenie Galicji m.in. R. Pelczer, Rzymskokatolickie szkoły trywialne w Galicji w latach 1774-1875, Lublin 2014.
} 
(dziewczynki) z okolicznych stron miały tu swój bezpieczny dom [...]”"46. Docierające do szkoły z pobliskich wsi uczennice, jak i wychowujące się przy klasztorze dziewczynki, stawały się współuczestniczkami, a niejednokrotnie wspóltwórczyniami organizowanych wydarzeń artystycznych, jednoczących lokalną społeczność i oddziałujących na nią w sposób rozwijający.

Siostry felicjanki cieszyły się uznaniem i dużym wsparciem ze strony Załuskich. Stwarzało to okazje do kontaktu panien $\mathrm{z}$ dobrego domu $\mathrm{z}$ formami szkolnictwa wiejskiego. Żona Michała Załuskiego, Helena z Brzostowskich ${ }^{47}$, zapisała w swym dzienniku pod datą 10 VII 1884 r. m.in. taką informację: „Widuję często proboszcza. Razem z Emcią przysłuchiwałyśmy się egzaminowi małych dziewczynek w szkole Felicjanek. Siostry wywierają dobry wpływ na naszych wieśniaków" ${ }^{\prime 4}$. W ten sposób „Emcia” - córka Michała i Heleny, wnuczka Amelii Ogińskiej - poznawała pewne elementy edukacji oddolnej, mogła także oceniać ich skutki jako bierna obserwatorka czynności egzaminacyjnych. Dzięki temu w arystokratycznej rodzinie, bywającej w wiedeńskich salonach i kształcącej własne dzieci w szkołach o najwyższym europejskim prestiżu, zaczęto doceniać pożyteczność szkół kościelnych i ich wkład w rozwój ludu. Należy w tym miejscu zaznaczyć, że wspomniana przez Helenę córka „Emcia” w 1884 r. liczyła sobie dwadzieścia jeden wiosen. Jej pierwszy kontakt z nauką wynikał z obserwacji zajęć Amelii Wysockiej ${ }^{49}$, która odwiedzając Iwonicz, na

\footnotetext{
46 M. Bliżycki, dz. cyt., s. 18-19.
}

47 Helena Brzostowska to nie tylko żona, ale także kuzynka Michała Załuskiego. Matką jej była siostra Amelii z Ogińskich Załuskiej, Emma.

\section{A. Kwilecki, Załuscy w Iwoniczu, s. 152.}

49 Amelia Wysocka była córką Emmy Ogińskiej (siostry Amelii z Ogińskich Załuskiej) i Antonina Wysockiego. Przeniesienie się w 1874 r. z Cieszyny do Krakowa umożliwiło jej rozwinięcie swego wielkiego talentu malarskiego, dzięki zapisaniu się na Wyższe Kursy dla Kobiet, organizowane przez Adriana Baranieckiego na uniwersyteckim Wydziale Sztuk Pięknych. Szkolenie odbywała w czasie, gdy wydziałem kierował Jan Matejko, u którego pobierała także lekcje prywatne. Jej obrazy: Dziad czytający książkę oraz Młody góral z Odrzykonia otrzymały nagrodę na wystawie paryskiej w 1879 r., a wiele innych przyczyniło się do olbrzymiej popularności w świecie malarzy. W periodyku Czas z 1880 r. krytyk artystyczny Juliusz Mien zapisał: „[...] p. Amelia Wysocka posiada zalety najważniejsze dla malarza, bez których nie ma prawdziwych artystów: czuje piękno i umie je wyrazić. [...] Po p. Wysockiej najzdolniejszą z uczennic I oddziału malarskiego jest bez zaprzeczenia panna Maria Jackowska [...]. I w tym przypadku zmiana miejsca stałego pobytu na terenie Galicji wpłynęła pozytywnie na przebieg kształcenia; H. Wysocki, dz. cyt., s. 265; J. Rostafiński, Historya Kursów Wyższych dla Kobiet im. A. Baranieckiego oraz Sprawozdanie Dyrekcyi za rok szkolny 1899/1900 istnienia kursów XXXII, Kraków 1900, s. 5-7, http://pbc.up.krakow. $\mathrm{pl} /$ dlibra/docmetadata $? \mathrm{id}=2630 \&$ from $=$ pubindex\&dirids $=163 \& \mathrm{lp}=1$ [dostęp 5 VI 2019]. 
oczach swej rocznej wówczas kuzynki „pisała dyktanda francuskie, czytała historię Anglii, uczyła się geografii, gimnastyki i tańca"s0. Poprzez częste przyjazdy do uzdrowiska z Cieszyny przyczyniała się do potwierdzania w rodzinie wzorca sumiennego zdobywania wiedzy. Opisane czynności utrwalały się na zawsze w obrazach najdawniejszych dziecięcych wspomnień.

Sama „Emcia”, wraz z bratem Józefem, również od najmłodszych lat pobierała nauki w domu, co nie przekładało się jednak na odseparowanie od spraw wsi. Najpierw dzieci zostały powierzone pod opiekę pochodzącej ze Śląska wychowawczyni, Frau Linke, od której uczyły się języka niemieckiego, czytania oraz pisania. Jak podaje Kwilecki, bona "chodziła z nimi na spacery, odwiedzała ludzi na wsi” ${ }^{1}$. Z kolei Angielka Isabella Stafford Hall odpowiadała za znajomość języka angielskiego przez młodych Załuskich. W zakres nauk domowych wchodziła także nauka muzyki, poznawanie polskiej historii i literatury ojczystej. Z korespondencji Michała Załuskiego dowiadujemy się, że koszty edukacji domowej były znaczne i wymagały dodatkowego zdobywania środków ${ }^{52}$. Niemniej przywołana przez niego w jednym z listów złota myśl, głosząca, że „lepiej dziecko uczyć, niż mu dawać pieniądze lub kosztowne prezenty" ${ }^{53}$, przez wszystkie lata przyświecała rodzicom Emmy i Józefa.

Przebiegu kształcenia nie mogły zaburzyć podróże wypoczynkowe, dlatego na czas swych zimowych wizyt w tyrolskim Gries ${ }^{54}$ zabierano ze sobą Frau Linke, na miejscu zaś zatrudniano tymczasowo innych nauczycieli. Późniejsze miejsca domowej edukacji „Emci” uzależnione zostały od dalszych etapów rozwoju jej brata. Kiedy Józef zaczął uczęszczać do gimnazjum św. Jacka w Krakowie, wymusiło to na całej rodzinie okresową migrację z Iwonicza do tego miasta. Poza tym w latach 1883-1885 chłopiec spróbował swych sił w Akademii Terezjańskiej w Wiedniu, co również wiązało się z częstym odwiedzaniem stolicy Austro-Węgier. Po tym czasie rodzice zdecydowali jednak o powrocie syna do Krakowa i dalszym kształceniu prywatnym, w trybie indywidualnym. Sezonowa obecność w Krakowie (podczas trwania roku szkolnego) stwarzała sposobność do rozwijania talentów Emmy. W domowym

\footnotetext{
50 H. Wysocki, dz. cyt., s. 135.

51 A. Kwilecki, Załuscy w Iwoniczu, s. 166.

52 Do swego brata Karola, Michał Załuski pisał w lutym 1877 r. m.in.: „(...) otrzymałem trochę pieniędzy dla Leny; te pieniądze przeznaczymy na naukę dzieci (...)”; [w:] A. Kwilecki, Załuscy w Iwoniczu..., s. 166.

53 A. Kwilecki, Zatuscy w Iwoniczu..., s. 166.

54 K.B. Załuski, dz. cyt., s. 196.
} 
zaciszu odbywała lekcje gry na fortepianie pod okiem niemieckiego kompozytora muzyki organowej, Juliusa Blaschke. Zajęcia z literatury polskiej, francuskiej i angielskiej, doskonalenie tych języków, jak również poszerzanie znajomości łaciny i języka niemieckiego, stanowiły podstawę programu. Dodatkowo młoda Załuska uczęszczała na lekcje tańca. Okresowa migracja krakowska, wyjazdy wiedeńskie, spotkania z nauczycielami domowymi, zbudowały wyobrażenie o edukacji całkowicie przeciwstawne wobec rzeczywistości, z jaką Emma miała się z czasem zetknąć w Iwoniczu. Dzięki podróżom i nauce Józefa dziewczyna uzyskała wszechstronne wykształcenie. Młodszy brat Michała Załuskiego, Karol Bernard, zapisał następujące wspomnienie z tego okresu, odnosząc się do sytuacji kulturalnej w Krakowie:

Gród Jagiellonów od dawna ma przywilej gromadzenia w swych murach rodzin z różnych dzielnic Polski przybyłych dla nauk szkolnych ich synów. Towarzyskie życie, zwłaszcza w zimowej porze, jest tam więc zawsze bardzo ożywionem. Korzystali z tego państwo Załuscy, aby swym dzieciom przysporzyć przyjemnych znajomości w młodym świecie, obok nauk udzielanych im przez wytrawnych nauczycieli ${ }^{55}$.

Dalej czytamy o predyspozycjach bratanka i bratanicy w pobieraniu wszelkich nauk. W zapisie nie odnajdujemy jakiegokolwiek rozróżnienia w prezentowaniu poziomu intelektualnego bądź stopnia rozwoju Emmy i Józefa, które mogłoby wynikać np. z odmiennego sposobu kształcenia. W przekazie stryjowskim oboje zdają się posiadać takie same umiejętności, wiedzę i bogate wyobrażenie o świecie. Wspomnienie doskonałej pamięci przodków zdradza, że w rozumieniu piszącego nie sama tylko edukacja i pracowitość decydowały o horyzontach myślowych uczniów. Do szkoły trafić musiał młodzieniec zaopatrzony w dziedziczną gotowość do zgłębiania tajemnic świata nauki. Również pod opieką nauczycieli domowych mogła rozwinąć się kobieta-geniusz, o ile pochodzenie rodowe stwarzało ku temu warunki. Z tego powodu „hrabianka Emma i jej brat zawczasu odznaczali się niezwykle dobrą, u nich dziedziczną po przodkach pamięcią, dzięki której z łatwością przyswoili sobie cztery języki, oprócz ojczystego, a przy wielkiem zamiłowaniu do książek, do nauk przyrodniczych i sztuk pięknych, zdobyli wykształcenie wszechstronne" ${ }^{36}$. Niemały wpływ na rozwój miała atmosfera patriotyczna Krakowa - „Emma i Józio słyszeli niemal codziennie o naukowych lub literackich zasługach wybitnych polskich uczonych

55 K.B. Załuski, dz. cyt., s. 197.

56 Tamże, s. 197. 
i pisarzy, najczęściej członków akademii umiejętności i profesorów wszechnicy Jagiellońskiej"s7.

Załuscy mieszkali w Krakowie łącznie przez siedem lat. Pierwsze pięć poświęcone zostało nauce dzieci, dwa ostatnie zaś przeznaczono na znalezienie męża dla Emmy. Dopiero teraz jej wszechstronna wiedza, poglądy, kultura osobista i znajomość dobrych obyczajów mogły zaowocować podobnie, jak to się stało w przypadku jej ciotek, Emmy i Marii w 1849 r. Plan zawiódł, jednak powrót na stałe do Iwonicza w 1884 r. otworzył przed dziewczyną nowe perspektywy. Przede wszystkim wykazywała ona wielkie zamiłowanie do życia na wsi, zdolności hodowlane, zainteresowanie pracami gospodarskimi oraz sprawami rolników. Jej stała obecność wśród społeczności chłopskiej sprawiła, że „w latach późniejszych okoliczni ziemianie nazywali ją »chłopomanką «" ${ }^{\text {. }}$. Postawa ta sprzyjała także otwarciu się na kwestię przemian w szkolnictwie ludowym w Galicji i przyczyniła się do zwrócenia uwagi na zasady funkcjonowania szkoły przy klasztorze felicjanek. Różne postacie kształcenia spotkały się w świadomości jednej osoby. Emma do końca życia pozostała niezamężna, natomiast jej brat związał się z Izą Tyszkiewicz-Łohojską herbu Leliwa z Krakowa. Mieli oni pięcioro dzieci, w tym jedną tylko córkę, Zofię Helenę, urodzoną w Iwoniczu w roku $1898^{59}$. Pierwszy ich syn, Michał, między siódmym a czternastym rokiem życia uczył się w Preparatory School, szkole z internatem w angielskim Brighton, następnie zaś w Wellington College. W Wielkiej Brytanii rozpoczynał swą naukę także jego młodszy brat, Karol. Po krótkim pobycie na Wyspach został przeniesiony do Terezjanum, i ostatecznie do seminarium duchownego w Rzymie. Zrezygnował jednak z tej drogi po dwóch latach. Trudności ze zdobyciem wykształcenia dotknęły najmłodsze dzieci Józefa i Izy - Ireneusza i Bogdana - którzy ze względu na wybuch pierwszej wojny światowej nie mogli wyjechać do Anglii. Przyczyniło się to do zwiększenia migracji rodziny. Początkowo chłopcy rozpoczęli naukę w szkole zakonu pijarów w Krakowie, ale po zajęciu budynku przez wojsko w 1914 r. konieczne stało się umiejscowienie jej w Wiedniu. Niesprzyjające warunki zmotywowały rodziców do przeniesienia synów do niedalekiego Kalksburga, gdzie funkcjonowała szkoła i internat przy zakonie jezuickim ${ }^{60}$. Mała Zosia, dzięki ciągłym podróżom z rodzicami oraz wzrastaniu pod opieką bon-cudzoziemek, szybko opanowała biegle

57 Tamże.

58 A. Kwilecki, Załuscy w Iwoniczu, s. 171.

59 http://www.sejm-wielki.pl/b/cz.I004085 [dostęp 6 VI 2019].

60 A. Kwilecki, Załuscy w Iwoniczu, s. 181. 
języki francuski, włoski, angielski, niemiecki oraz szwedzki. Naukę tańca odbywała kolejno w Warszawie i we Florencji, pod okiem włoskiego tancerza Enrico Cecchettiego. Wyjazd Załuskich na zimę do Anglii w 1908 r., w celu odwiedzenia uczących się tam synów, umożliwił jej uczęszczanie do szkoły dla dziewcząt w Londynie ${ }^{61}$.

Aby nakreślić migracje na ziemiach Galicji wśród członkiń prezentowanej rodziny, cofnijmy się jeszcze do pokolenia Michała i Heleny Załuskich. Siostrzeniec Michała, kuzyn jego dzieci: „Emci” i Józefa - Stanisław Hieronim Ostaszewski - w maju 1900 r. poślubił w Krakowie Anielę Zofię Sękowską. Urodziła się ona 27 IV 1882 r. w Sannikach, jako córka Feliksa Kacpra Sękowskiego i Ludmiły z Bernatowiczów (herbu Suchekomnaty), właścicieli majątków Sanniki i Mistyc ${ }^{62}$ w powiecie przemyskim. Straciwszy kolejno matkę i ojca w wieku odpowiednio dwóch i trzech lat, Aniela zamieszkała w majątku swego stryja - Jana Edwarda Sękowskiego ${ }^{63}$ - w Wydrnej. Wraz z żoną, Wiktorią, zapewnił on bratanicy rodzicielską opiekę. Po śmierci stryjostwa, od 1896 r., wychowawczynią dziewczynki została jej stryjeczna siostra, o trzydzieści lat od niej starsza Bronisława Sękowska ${ }^{64}$. Aniela zdobyła wykształcenie $\mathrm{w}$ przyklasztornej szkole sióstr niepokalanek w Jarosławiu ${ }^{65}$ oraz szkole pensjonatowej przy zespole klasztornym sióstr urszulanek w Krakowie ${ }^{66}$. Wydrną od Jarosławia dzieli w linii prostej odległość pięćdziesięciu jeden kilometrów. Współczesny przejazd między tymi miejscowościami rowerem liczy między siedemdziesiąt osiem, a osiemdziesiąt trzy kilometry i trwa około czterech i pół godziny. Przybliżony czas przejazdu standardową bryczką w XIX w. trwał jednak dłużej, co wynikało z konieczności postojów oraz trudności związanych z nierównościami podłoża, zalewaniem

61 Tamże, s. 182.

62 Ziemianie polscy XX wieku. Słownik biograficzny, część 11, red. T. Epsztein, Warszawa 2016, s. 53.

63 Pokrewieństwo dostępne jest na stronie potomków Sejmu Wielkiego, http://www.sejm-wielki.pl/s/ ?lang=;em=R\&ei=171497\&m=NG\&select=input\&t=PN\&et=S\&image=off\&spouse $=$ on \&n $=$ sw.6471 [dostęp 6 VI 2019].

64 K. Soltysik, Wstęp, [w: ] A. Ostaszewska, Dziennik Klimkówka 2 VIII 1914-24 IV 1915. Dwór Ostaszewskich. Galicyjski epizod z Wielkiej Wojny, oprac. K. Sołtysik, Klimkówka 2016, s. 14; zob.: http://www.sejm-wielki.pl/b/sw.7554 [dostęp 6 VI 2019].

65 Szkoła ta została utworzona w 1875 r., po przeniesieniu z Jazłowca (obecnie na Ukrainie) przez założycielkę Zgromadzenia, Matkę Marcelinę Darowską. Więcej informacji o szkole w: E. Jabłońska-Deptuła, Marcelina Darowska niepokalanka 1827-1911, Lublin 1996, oraz na stronie: http://klasztor.niepokalanki.edu.pl/joomla30/index.php/klasztor [dostęp 11 VI 2019]. 66 K. Soltysik, Wstęp, [w:] A. Ostaszewska, dz. cyt., s. 15. 
dróg lub ślizganiem się koni. Przyczyniało się to do pozostawania w przyklasztornym internacie nieraz przez wiele tygodni i powracania do rodzinnej miejscowości jedynie przy okazji obchodów ważniejszych świąt i uroczystości. Taka sytuacja sprzyjała wytwarzaniu się silniejszej więzi między nauczającymi siostrami, a ich podopiecznymi, dla których stawały się one wyznacznikami systemu wartości i zasad moralnych.

Nieustanne podróże Załuskich i ich krewnych w obrębie Galicji, jak również konieczność opuszczania jej i migracji po Europie w celu edukacji potomstwa płci męskiej doprowadziły do uzyskiwania niezwykle bogatego i różnorodnego wykształcenia przez dziewczęta z tej rodziny. Nie tylko korzystały one z usług nauczycieli domowych w obcych państwach, ale poznawały tamtejsze tradycje i obyczaje, a obracając się w kręgach śmietanki intelektualnej XIX w., brały udział w dyskusjach z wielu dziedzin nauki. Migracja „za szkołą” stwarzała młodym arystokratkom doskonałą okazję do poszerzania horyzontów, zdobywania wiedzy, a jednym z największych profitów była znajomość przez nie licznych języków obcych. Pozostałości po magnackim kosmopolityzmie z okresu I Rzeczypospolitej dawały się odczuć jeszcze $\mathrm{w}$ trzecim i czwartym pokoleniu, uzewnętrzniane $\mathrm{w}$ formie wytrwałego poszukiwania jak najlepszych miejsc do rozwoju. Zarazem druga połowa XIX w. zapoczątkowała w Iwoniczu okres edukacji dziewcząt ze wsi. Przekonanie panien o ich wyłącznym obowiązku kształcenia się ulegało stopniowo neutralizacji. Podsumowanie to wymaga jednak pewnego uzupełnienia zgodnie ze wstępnym założeniem o wielkim wpływie migracji na rozwój dziewcząt. W perspektywie stulecia ujawnia się ciąg przemian w mentalnym pojmowaniu zależności między zdobywaniem wiedzy a przemieszczaniem się całych rodzin bądź niektórych ich członków. Za impuls wywołujący owe przemiany można uznać oddziaływanie sytuacji dziejowej, specyficznej ze względu na konieczność zachowania i przekazania potomstwu pamięci o dawnej rzeczywistości magnackiej.

W pierwszym etapie porozbiorowym w rodzinach szlacheckich nadal istniały nadzieje na odzyskanie władzy, własnego państwa i realnego znaczenia na arenie międzynarodowej. Podróżujących podejmowano na dworach najznamienitszych polityków epoki, a ich córkom przysługiwało kształcenie na najwyższym poziomie, niejako przy okazji tych wizyt. Na początku XIX w. możemy mówić o „podróżach kształcących”, w świadomości dzieci stanowiących dodatkową atrakcję ich luksusowego życia. Dotkliwa porażka powstania listopadowego przekierowała uwagę rodziców z wielkich projektów politycznych ku działalności domowej, a przestrzeń życia rodzinnego stała się jedyną, w której można było pielęgnować mit niepodległościowy. Równocześnie edukacja córek przez matki zmierzała do zaopatrzenia 
panien w nowoczesną wiedzę, która pozwoliłaby im utrzymać swe znaczenie w środowiskach magnackich Europy. Naznaczeniu uległy również podróże - poszukiwano godnego wykształcenia oraz nowego miejsca i nowych szans dla swego potomstwa. Nastąpił etap realnej „migracji za wiedzą”, jednak jej zdobywanie w cenionych szkołach szlacheckich nie zdołało wynagrodzić strat obywatelskich, poniesionych po roku 1795. Na przełomie lat czterdziestych i pięćdziesiątych XIX w. głód dydaktyczny asymilował się z rzeczywistością galicyjską. Nasilił się kontakt szlachcianek z chłopstwem, zwłaszcza na płaszczyźnie pomocy społecznej i wspierania szkół dla ludu. Reformy austriackie dawały nadzieję na ustabilizowanie kwestii edukacji, zwiększały mobilność społeczną i doprowadziły do zbliżenia między stanami. W ten sposób szkolnictwo weszło stopniowo w fazę „powszechności”. Dwie ostatnie dekady omawianego stulecia to czas wzrostu znaczenia szkół na terenie Galicji, zwłaszcza w Krakowie, w oczach zamożnych rodów herbowych. Ta forma kształcenia dzieci współistniała nadal z wyjazdami poza zabór austriacki, jednak migracja głównie regionalna była oznaką ochłonięcia narodu po wydarzeniach, do których doszło od czasu kongresu wiedeńskiego. Po „obyciu się z migracją dydaktyczną” nastąpiło wyciszenie społeczne i osłabienie zjawiska pogoni za wykształceniem. Urodzeni pod koniec XIX w. potomkowie Józefa i Izy Załuskich do chwili wybuchu pierwszej wojny światowej mogli korzystać z dobrodziejstw tej stabilizacji. Odbywając liczne podróże po Europie w celu pobierania nauk w ekskluzywnych szkołach, byli zarazem w pełni świadomi konieczności powszechnego kształcenia, nieuzależnionego od płci, zamożności czy statusu społecznego. Po stu latach zrekonstruował się model „podróży kształcących”, uzupełniony o doświadczenia migracyjne, z których każde poszerzało horyzonty myślowe potomków Amelii z Ogińskich Załuskiej. Mobilność okazała się niezwykle cenna dla dziewcząt nie tylko z powodu zdobywania wiedzy, lecz także różnorodności przeżyć, poznawania odmiennych realiów życia i układów społeczno-politycznych, wreszcie ze względu na mnogość stworzonych więzi międzyludzkich.

Reasumując, należy stwierdzić, że w odniesieniu do omawianych rodów wyraźnie zarysowało się wielkie poświęcenie i zaangażowanie matek w sprawę edukacji potomstwa. Córki uczestniczyły na równi ze swymi braćmi we wszystkich podróżach kształcących, dzieląc wraz z nimi obowiązek nieustannej zmiany miejsca zamieszkania. Ze wspomnień matczynych możemy wnioskować o uciążliwości tego sposobu funkcjonowania i odczuwaniu tęsknoty za stabilizacją. Niezależnie od tej postawy presja tradycyjnego, arystokratycznego modelu kształcenia motywowała do jego kontynuowania kolejne pokolenia. Zdobywanie wiedzy, doświadczenia i obycia 
przez córki umożliwiało matkom realizowanie zadań przewodniczek i strażniczek ich przyszłości oraz zachowanie przez rodzinę poczucia wyższości społecznej.

\author{
Mgr Małgorzata Gumper \\ Uniwersytet im. Adama Mickiewicza w Poznaniu \\ Wydział Historii \\ ul. Uniwersytetu Poznańskiego 7 \\ 61-614 Poznań \\ e-mail: malgorzata.gumper@vp.pl \\ Nadesłany 17 X 2019 \\ Nadesłany po poprawkach recenzyjnych 28 VIII 2020 \\ Zaakceptowany 10 IX 2020
}

\title{
Summary
}

In the $19^{\text {th }}$ century many of eminent magnate families had to secure the future of their children in difficult conditions after the liquidation of the political nobility nation. The reaction to this situation was, among others providing descendants with a good education so that they can make a career in European mansions and armies in the future. Girls took part in many educational journeys, which gave them a chance to learn about the different realities of social and cultural life. The history of the Załuski family showed also the process of assimilation of daughters with new form of education, when church and country schools began to spread in Galicia in $19^{\text {th }}$ century. Extremely different ideas about education functioned together in the consciousness of this generation of aristocrats, who lived to see independence. This article shows all these changes based on fragments of family memories about educational migrations. 